\title{
Trophic models and short-term dynamic simulations for benthic-pelagic communities at Banco Chinchorro Biosphere Reserve (Mexican Caribbean): a conservation case
}

\author{
F.A. Rodríguez-Zaragoza1,7, M. Ortiz², F. Berrios², L. Campos², A. de Jesús-Navarrete³, \\ J. Castro-Pérez ${ }^{4}$, A. Hernández-Flores 5 , M. García-Rivas 6 , F. Fonseca-Peralta ${ }^{6}$ and \\ E. Gallegos-Aguilar6
}

${ }^{1}$ Depto. de Ecología, CUCBA, Universidad de Guadalajara. Carr. Guadalajara-Nogales Km. 15.5, Las Agujas Nextipac, Zap., C.P. 45110, Jal., México

2 Instituto Antofagasta, Instituto de Ciencias Naturales AvH, Facultad de Ciencias del Mar y Recursos Biológicos, Universidad de Antofagasta, Antofagasta, Chile

${ }^{3}$ ECOSUR-Chetumal. Av. del Centenario Km. 5.5, C.P. 77900, Chetumal, Q. Roo, México

${ }^{4}$ Inst. Tec. de Chetumal. Av. Insurgentes No. 330, Col. David Gustavo Gutiérrez, C.P. 77013, Chetumal, Q. Roo, México

${ }_{5}^{5}$ RIP, Instituto Nacional de Pesca, Carr. a Chelem, Boulevard del Pescador S/N, Puerto de Abrigo, Yucalpetén, C.P. 97320 , Yuc., México

${ }^{6}$ Comisión Nacional de Áreas Naturales Protegidas. Insurgentes No. 445, C.P. 30206, Chetumal Q. Roo, México

${ }^{7}$ Corresponding author. E-mail: rzf39259@cucba.udg. Telephone: +(52) 3337771156

Keywords: Coral reef, Ecopath with Ecosim, Network properties, Trophic dynamics.

\begin{abstract}
Banco Chinchorro is the largest reef in the Mexican Caribbean. Historically, spiny lobster, queen conch and over 20 other reef species have been exploited here. Multispecies intervention management from an ecosystem perspective has been developed in this area; however, an assessment of the effects of such practices on ecosystem health is required. Five quantitative trophic models were constructed using Ecopath with Ecosim. The results show that, in terms of biomass, benthic autotrophs are the dominant group in all communities. Ecosystem Network Analysis indices showed that Cueva de Tiburones was the most mature, developed, complex and healthy subsystem, but, El Colorado and La Baliza were the subsystems most resistant to disturbances. The fisheries mainly concentrate on primary (La Baliza and Cueva de Tiburones sites) and secondary consumers (La Caldera, Chancay, and El Colorado). The greatest propagation of direct and indirect effects, estimated by Mixed Trophic Impacts and Ecosim simulations, were generated by the benthic autotrophs, small benthic epifauna, benthic-pelagic carnivorous fish and benthic carnivorous fish, among others. In contrast, the System Recovery Time showed different patterns among subsystems, indicating several compartments that reduce resilience. Considering the structure, dynamics, trophic functioning and ecosystem health of Banco Chinchorro, its ecological heterogeneity highlights the need for the design of a specific (by subsystem) management strategy, particularly because different species or functional groups present greater sensitivity to human interventions in each community.
\end{abstract}

Nomenclature: Humann and DeLoach (2013a,b), Robertson et al. ( 2015).

Abbreviations: EBFM- Ecosystem-Based Fisheries Management, MBRS- Mesoamerican Barrier Reef System, MTI-Mixed Trophic Impacts, RDA-Redundancy Analysis ordination, PERMANOVA-Permutational Multivariate Analysis of Variance, SRT-System Recovery Time, T-Total System Throughput.

\section{Introduction}

Banco Chinchorro, one of the largest platform coral reefs in the Caribbean Sea (Jordán and Martín 1987), is located at the northern end of the Mesoamerican Barrier Reef System (MBRS). In 1996, the Mexican government declared this reef a Biosphere Reserve in order to protect its biodiversity, maintain its ecological processes (ecosystem health) and manage its natural resources (INE, 2000). With the excep- tion of fishing activities, this isolated reef has experienced little impact from tourism and human coastal settlements (Chávez and Hidalgo 1987). The Banco Chinchorro area has been subject to artisanal fisheries for over 40 years. These fisheries mainly target the Caribbean spiny lobster (Panilurus argus), queen conch snail (Strombus gigas), and various fish species (Sosa-Cordero 2003) and have had a negative impact on $P$. argus and $S$. gigas, decreasing their abundance since the late 1980s (de Jesús-Navarrete et al. 2003). Strombus gigas 
and $P$. argus are currently considered to be over-exploited resources (de Jesús-Navarrete et al. 2003). In order to help the populations recover, the fishing authority (dependent on the federal government) has implemented minimum extraction sizes and bans on the exploitation of S. gigas (February, May-November) and $P$. argus (March-June). Furthermore, catch quotas have been established for $S$. gigas. Although the fishing cooperatives have complied with these management measures, illegal fishing has caused landings to reach a critical state, negatively affecting the abundance of these resources and the local economy for the legal fishermen (de Jesús-Navarrete et al. 2003). While the effects of the exploitation of reef fish of the families Serranidae, Lutjanidae, and Haemulidae on Banco Chinchorro have not been assessed as a whole, it is accepted that the extraction of predatory fish acts to reduce predation pressure and affects the top-down control exerted by these species in coral reef networks (Pauly et al. 1998), indirectly impacting the population dynamics of P. argus (Sosa-Cordero 2003), S. gigas (de Jesús-Navarrete et al. 2003) and possibly the whole reef fish assemblage.

Several studies have been carried out in this protected reef, including: (1) oceanographic dynamics (Merino-Ibarra 1986), (2) bathymetric analysis (González et al. 2003), (3) reef fish ecology (Villegas-Hernández et al. 2008), (4) coral taxonomy (Beltrán-Torres and Carricart-Ganivet 1999), (5) coral growth and recruitment estimates (Cruz-Piñón et al. 2003) and (6) evaluations of the effects of hurricanes on hard corals (Beltrán-Torres et al. 2003). Very few fishing studies have been conducted, and these have focused mainly on P. argus and S. gigas (de Jesús-Navarrete et al. 2003, Sosa-Cordero 2003). Presently, only population-level fishing management strategies have been developed, omitting any consideration of ecological relationships and ecosystem health properties. It was therefore necessary to collect bio-ecological information pertaining to the commercial species and those ecologically related to them in order to design and apply (at a fine spatial scale) a program of Ecosystem-Based Fisheries Management (EBFM). Based on this analytical strategy, it is possible to incorporate the needs of the different stakeholders involved (i.e., authorities, fishermen, tourism service operators), ensuring the implementation of an ecologically and holistically sustainable (healthy) multi-species co-management strategy (Ortiz 2008, Ortiz et al. 2010, 2013, 2015).

For many years, the scientific community has attempted to assess and predict the effects of fishing on the functioning of aquatic ecosystems (Walter et al. 1999, Francis et al. 2007, Ortiz et al. 2010, 2013, 2015). This has promoted a change in the scientific perspective, focusing it on the ecological interrelationships that occur in ecosystems instead of concentrating only on the protection and dynamics of isolated populations (Scotti et al. 2012). In this sense, ecosystem models may be considered complementary tools for population studies. Multi-species mass balance models can be constructed using Ecopath with Ecosim software (Christensen and Walters 2004), which allows the application of Ecosystem Network Analysis (Ulanowicz 1986, 1997). Within this theoretical framework, Ascendency is one of the system-level indices used to detect early signs of stress within a whole ecosystem
(Bondavalli et al. 2006). Supported by Ascendency, some explorations have been conducted with regard to the properties, dynamics and global health of ecosystems (Costanza et al. 1998). Likewise, Ecopath has been widely used to evaluate - at different spatial scales - the effects generated by various scenarios of marine ecosystem exploitation (e.g., Ainsworth et al. 2008, Ortiz et al. 2010, 2013, 2015, Arias-González et al. 2011, Weijerman et al. 2013).

Recently, there has been significant progress in the construction of ecosystem models in coral reefs. These have mostly described the structure of food webs, trophic functioning and possible effects of fishing (e.g., Polovina 1984, Ainsworth et al. 2008, Arias-González et al. 2011, Weijerman et al. 2013). Only Ainsworth et al. (2008), Arias-González et al. (2011), and Cáceres et al. (2016) have assessed different fishing management scenarios from an EBFM perspective in coral reef systems. The objective of the present study was to build multispecies trophic models that consider relationships between species and/or functional groups in five different reef areas (subsystems) at Banco Chinchorro Biosphere Reserve. These areas were selected $a$ priori, compiling the viewpoints and demands of managers, fishermen, tourism service operators and researchers regarding the design and execution of sustainable fishing management strategies. An ecological system would be considered healthy if it is sustainable, meaning that it maintains its function and organization over time and is resilient against disturbances (Costanza et al. 1998). Thus, the following ecological aspects were evaluated in each subsystem: (1) biomass distribution and trophic flows; (2) ecosystem organization, maturity, degree of resistance to disturbances and the resilience measured as system recovery time (considered as indicators of health); (3) propagation of the direct and indirect effects of fishing among species and functional groups; and (4) identification of the species and/ or functional groups most affected by different scenarios of human intervention.

\section{Material and methods}

\section{Study area}

Banco Chinchorro is located $30.8 \mathrm{~km}$ to the south-west of the Yucatán Peninsula and is separated from the continent by a channel $\sim 500 \mathrm{~m}$ in depth (Vega-Zepeda et al. 2007) (Fig. 1). Banco Chinchorro is ovoid in shape, measuring $43.2 \mathrm{~km}$ in length and $18.0 \mathrm{~km}$ in width (INE 2000). The reef lagoon is surrounded by a semi-continuous barrier reef with a perimeter of $\sim 115 \mathrm{~km}$, an area of $>500 \mathrm{~km}^{2}$ and depths of between 1 and $9 \mathrm{~m}$. The reef includes four cays that cover $\sim 0.4 \%$ of the total reserve surface, the sea water is oligotrophic with surface water temperatures that fluctuate between 27 and $29^{\circ} \mathrm{C}$ and a salinity that ranges from 36.6 to $36.9 \%$ (INE, 2000). We studied five reef areas of conservation interest (Fig. 1). The main benthic habitat features of each area (subsystem) at Banco Chinchorro are described in Appendix A. We assume these five areas to constitute subsystems with different ecological properties, which is supported by a previous ecological analysis showing that these areas were significantly different in terms of 
benthic habitat structure and reef fish assemblages (Fig. 1). For details on sampling methods and multivariate analyses, see Appendix B. The strategy of building mass balance networks that are based on subsystems (low spatial scale) allows the description and assessment of the consequences of human intervention in greater detail (e.g., Arias-González et al. 2004, Ortiz 2008, Ortiz et al. 2010, 2013, 2015).

\section{Ecopath and Ecosim modelling approach}

This study uses the Ecopath with Ecosim software (www. ecopath.org) to construct trophic mass-balance models. Ecopath incorporates the approach of Polovina (1984), who estimated biomass and food consumption of ecosystem variables or functional groups. Extended versions of Ecopath have been provided by Christensen and Pauly (1992) and Walters et al. (1997). The Ecopath software permits a steady-state description of the matter/energy flow within an ecosystem at a particular time, whereas Ecosim enables dynamic simulations based on an Ecopath model, allowing estimation of ecosystem changes as a consequence of a given set of perturbations (Appendix C).

\section{Whole system indices}

Ecopath with Ecosim also includes the Ecosystem Network Analysis (Ulanowicz 1986, 1997), which analyzes flows among the compartments of a system in order to calculate several whole system indices: i) Total System Throughput $(T)$, which describes the size of the system in energetic terms

(A) Study area, subsystems and sampling sites

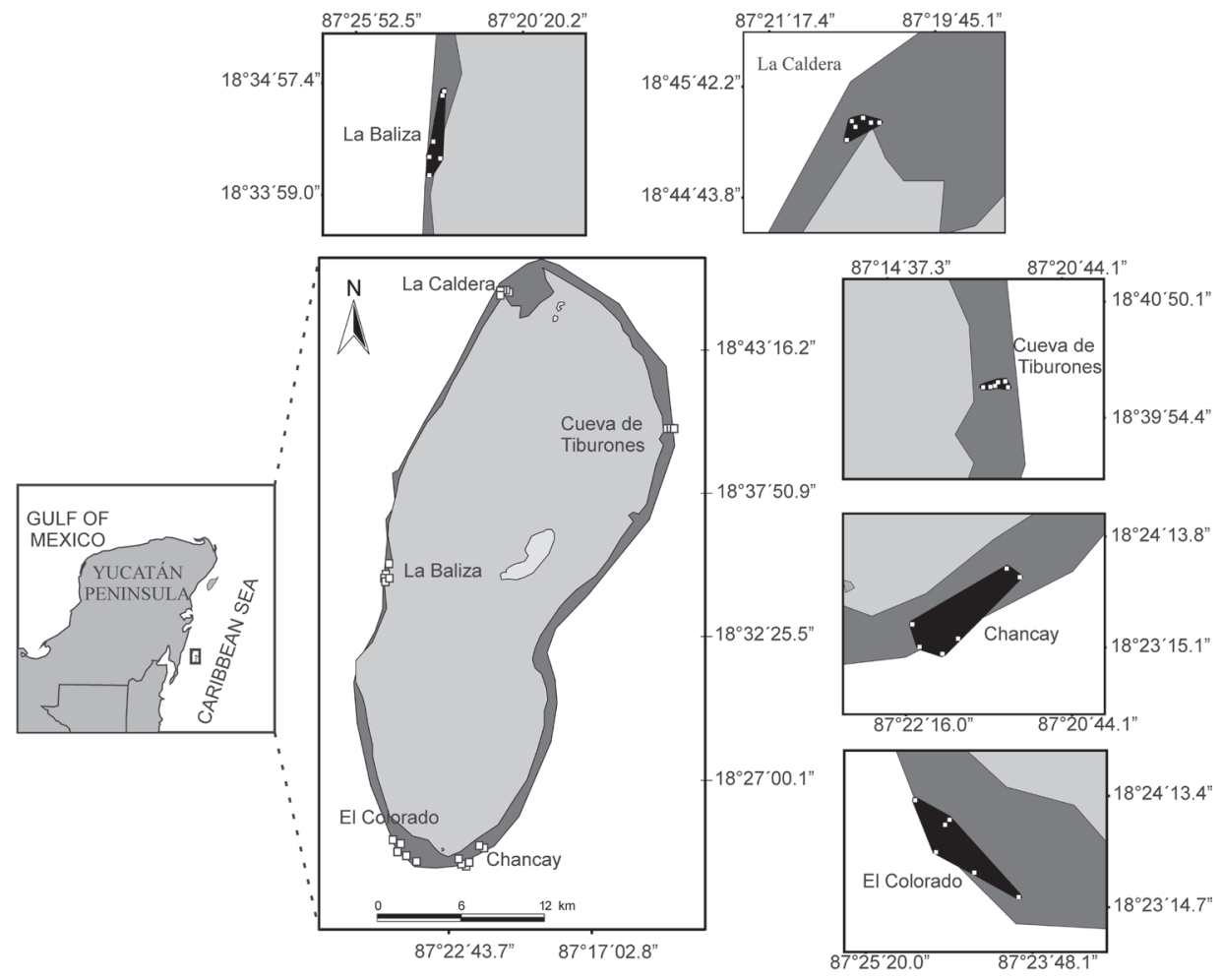

(B) NMDS and PERMANOVA

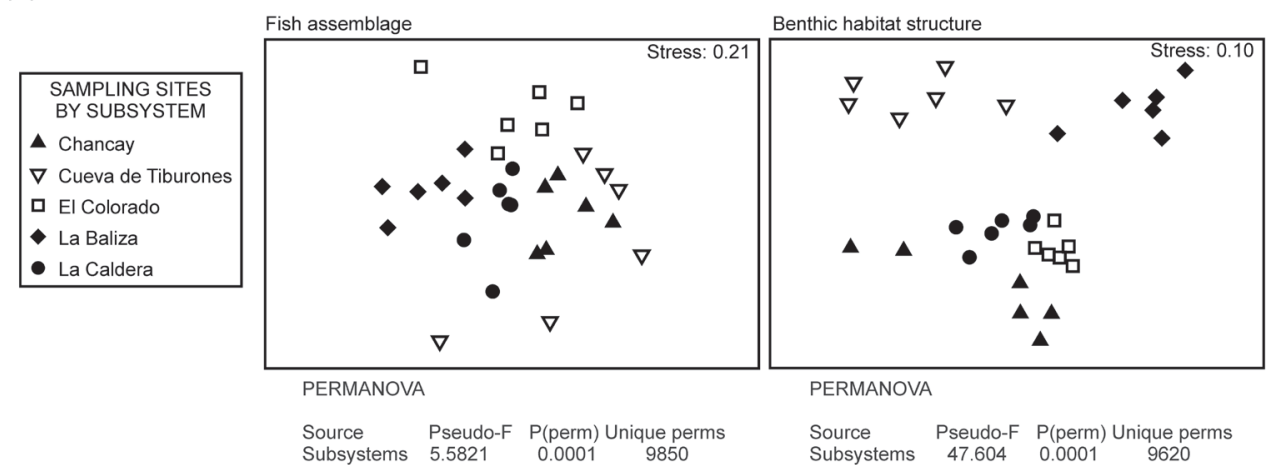

Figure 1. Study area and fishing areas at Banco Chinchorro Biosphere Reserve, Mexico. (A) Fishing areas (subsystems) and sampling sites (open squares). (B) Variation of fish assemblages and benthic habitat structure among subsystems. Non-metric multidimensional scaling (NMDS) and one-way PERMANOVA were performed with Bray-Curtis similarity matrices. 
and provides a measure of its metabolism; ii) Ascendency (A), which considers the size and organization of the system, the latter corresponding to the number and diversity of interactions among its compartments; iii) Development Capacity (C), which quantifies the upper limit of Ascendency, while the $A / C$ ratio is an index of maturity that describes the maximum degree of specialization reached by the system. Likewise, $A / C$ and Internal Redundancy (or Overhead's internal flow) are important attributes of ecosystem stability that represent the organization of the system; iv) Overhead $(\mathrm{Ov})$, which is a measure of the energy in an ecosystem that is available to resist perturbations, particularly expressed as $O v / C$ ratio. Ascendency and Overhead have been shown to be related to stability and maturity; v) Mean Length of Pathways, which corresponds to the average number of groups passed through by an inflow or outflow and increases with ecosystem maturity; vi) System Omnivory Index, which represents how feeding interactions are distributed in relation to trophic levels, providing a measure of the system complexity (Ulanowicz 1986, 1997, Christensen 1995). Ecopath and Ecosim models and these macro-descriptors have been widely used to compare and describe multiple ecosystems of different sizes, geographic locations and complexities (e.g., Monaco and Ulanowicz 1997, Guénette et al. 2008, Arias-González et al. 2011, Ortiz 2008, Ortiz et al. 2010, 2013, 2015, Cáceres et al. 2016).

\section{Selection of model compartments, sampling program and data sources}

For each of the five study areas, a trophic model was constructed with compartments representing species and functional groups. The selected species were organisms of economic importance (e.g., S. gigas, P. argus and the fish species Mycteroperca bonaci, Sphyraena barracuda, Epinephelus striatus, Lutjanus griseus, Lutjanus analis, Lachnolaimus maximus). For fish, functional groups were created for benthicpelagic carnivorous fishes, piscivorous fishes, benthic carnivorous fishes, zooplankton feeders, omnivorous fishes and herbivorous fishes. Other groups were the large benthic epifauna, sea urchins, soft corals, small benthic epifauna, zooplankton, stony corals, sponges, benthic autotrophs, symbiotic algae (zooxanthellae), phytoplankton and detritus. It is important to indicate that the models did not share the same number of compartments. Appendix D shows the species included within the functional groups and the data sources for the models.

All of the compartments were connected to detritus, assuming that detritus includes microbial biofilm and organic matter. All compartments related to birds, marine mammals, turtles, bacteria, and sharks were excluded from the networks due to a lack of sufficient scientific information. While such an omission could decrease the realism of the constructed models, we consider that the most important trophic relationships and energy/matter flows within the compartments were incorporated into the models. Thus, this limitation should not prevent comparisons with other ecosystems that present similar limitations (see Arias-González et al. 2004, Ortiz 2008, Ortiz et al. 2010, 2013, 2015, Cáceres et al. 2016).

\section{Balancing and calibrating the models}

During the balancing procedure, the feasibility of the results was checked by verifying that all of the ecotrophic efficiencies $(E E)$ of the compartments were $<1.0$ (Ricker 1968). Where $E E$ was $>1.0$, the following procedure was applied: (1) for fishes, $S$. gigas, $P$. argus, soft corals, stony corals, sponges, sea urchins and benthic autotrophs, the biomass was adjusted \pm 1 standard deviation (SD) using the estimates obtained during field studies; the biomass of the remaining compartments was adjusted within previously published ranges (e.g., Opitz 1996, Arias-González et al. 2004, 2011, Ainsworth et al. 2008, Liu et al. 2009, Cáceres et al. 2016); and (2), the gross efficiencies $(G E)$ were reviewed and compared to ensure they were consistent with the data described in the literature $(P / Q$ $<0.30$ ) (Christensen and Pauly 1993).

\section{Assessment of multispecies fishery short-term impacts}

The Mixed Trophic Impacts (MTI) (Ulanowicz and Puccia 1990) - a sub-routine of Ecopath - was used to measure the strength of net direct and indirect effects that involve pairs of species or functional groups (Jordán et al. 2014). Shortterm dynamic simulations of Ecosim were used to evaluate the propagation of instantaneous direct and indirect effects and System Recovery Time (SRT), as an internal stability/ resilience measurement. The disturbance consisted of an increase of total mortality $(Z)$, equivalent to a $30 \%$ increase in total production $(P)$, where Production $=Z \times \operatorname{Biomass}(B)$. It is important to highlight that $Z$ is equivalent only to natural mortality $(M)$ for non-exploited species, or $Z=M+$ fishing mortality $(F)$ when there are target species. This intervention - as a similar perturbation - was performed between the first and second year of simulation for each species or functional group. The effect of the increased total mortality was determined by evaluating the biomass of all the variables of the systems in the third year of simulation, i.e., one year after the impact (short-term dynamics). The simulations were performed using several flow control mechanisms - or vulnerabilities $\left(v_{i j}\right)$ - that influence the energy transfer rate between two groups and represent top-down, mixed, or bottom-up controls (Appendix C). The Ecosim simulations (Ecopath with Ecosim software v.5.0) were performed with the following vulnerabilities: $v=0.0$ represents a bottom-up control, $v$ $=0.3$ mixed, and $v=1.0$ top-down. This strategy was adopted given the lack of time-series in the fishery landing data for the target species of each subsystem. This criterion has been used for other trophic models at comparable spatial scales for assessing ecosystem stability in terms of resistance and resilience (Ortiz 2008, Ortiz et al. 2010, 2013, 2015, Cáceres et al. 2016). In this study, stability is defined as the ability to return to a similar initial state following a disturbance (Holling 1973). Resistance describes the capacity of the system to withstand an external disturbance (Begon et al. 1990). Resilience can be defined as the speed at which a system returns to its original state following disturbance (Pimm 1982). Resistance and resilience are integral aspects 
of stability, such that we assume $S R T$ to be a measure of the internal stability of the modeled subsystems.

\section{Results}

The group of benthic autotrophs represented the highest portion of biomass ranging from 63.9 to $90.8 \%$ of the total system biomass, considering all subsystems (Appendix E, Table G1 in Appendix G). The benthic autotrophs had the highest biomass in the Cueva de Tiburones and La Baliza models. This group was followed by the soft corals with a relative biomass ranging from $1.4 \%$ to $21.7 \%$. The highest biomass of soft corals was located in El Colorado. Other functional groups with a low relative biomass in the five models were: detritus (1.5-2.3\%), small benthic epifauna (0.8-2.0\%) and sponges (0.6-8\%) (Appendix E, Table G1).

Table G2 in Appendix G summarizes the statistics and ecological network properties. Of the five trophic models, the highest total system biomass was estimated for Cueva de Tiburones (7823.4 $\mathrm{g} \mathrm{w} \mathrm{w} \mathrm{m}^{-2}$ ), while the other models presented similar values of total biomass $(B)$ (from 5045.7 to $5992.9 \mathrm{~g} \mathrm{w} \mathrm{w} \mathrm{m}^{-2}$ ). The highest total production was also found at Cueva de Tiburones $\left(99,544.2 \mathrm{~g} \mathrm{w} \mathrm{w} \mathrm{m}^{-2}\right.$ year-1 $^{-1}$, while the lowest was calculated for El Colorado (50,096.3 $\mathrm{g}$ w w m m $^{-2}$ year- $\left.^{-1}\right)$ and La Caldera $\left(64,216.7 \mathrm{~g} \mathrm{w} \mathrm{w} \mathrm{m}^{-2}\right.$ year $\left.^{-1}\right)$. Total consumption and total respiratory $(R)$ flows were higher in El Colorado than in the other models. Likewise, the Cueva de Tiburones model presented the highest sum of all flows to detritus. In terms of ecosystem structure and properties, the food webs differed among the five models. Trophic levels varied from 1.00 for primary producers and detritus to 3.3-4.3 for fish feeder organisms such as M. bonaci, S. barracuda, E. striatus and the piscivorous fish groups (Table G1). The highest connectance index values corresponded to the Cueva de Tiburones subsystem, while the lowest were estimated for El Colorado and La Baliza. In contrast, the system omnivory index and the mean length of pathways showed the highest values for El Colorado and La Baliza, while those of Cueva de Tiburones were the lowest (Table G2).

In relation to ecosystem growth and development, the Cueva de Tiburones model had the largest magnitude of $T$ $\left(203,580.5 \mathrm{~g} \mathrm{w} \mathrm{w} \mathrm{m}^{-2}\right.$ year-1 $\left.^{-1}\right)$, whereas the lowest value was obtained by the El Colorado model $\left(114,210.2 \mathrm{~g} \mathrm{w} \mathrm{w} \mathrm{m}^{-2}\right.$ year $\left.^{-1}\right)$. Likewise, Cueva de Tiburones presented the highest magnitudes of $A, C$ and $A / C$ ratio. Pathway redundancy and $O v / C$ ratio was highest for El Colorado and La Baliza. The five models cycled from 0.58 to $4.14 \%$ (Finn's cycling index) of $T$, of which El Colorado presented the highest magnitude (Table G2). In the case of the contribution made by each compartment to the overall structure and function $(A)$, detritus (36.6-43.1\%), benthic autotrophs (33.2-41.3\%), and

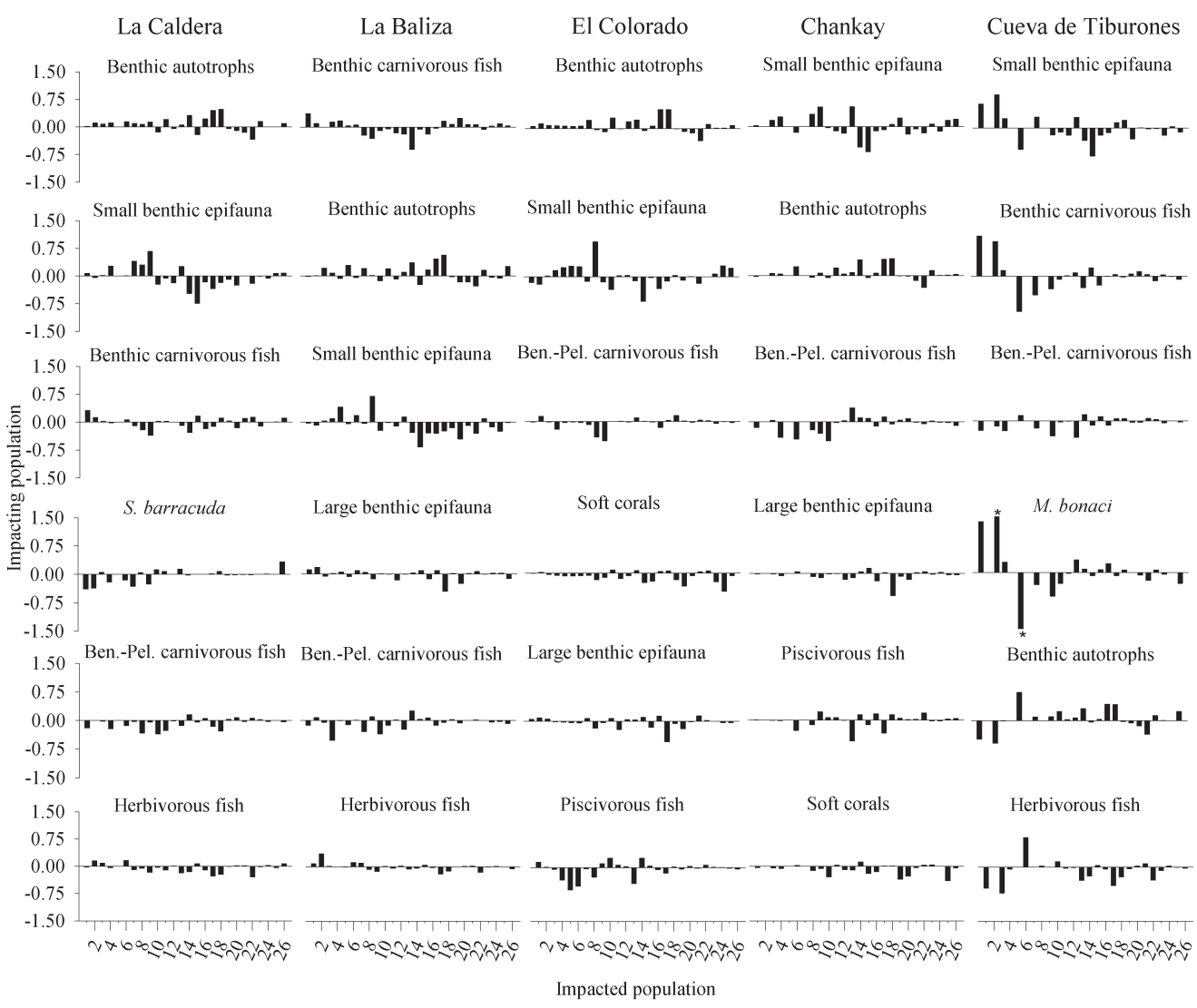

Figure 2. Mixed trophic impacts $(M T I)$ as response to the main impacting functional groups of five fishing areas at Banco Chinchorro Biosphere Reserve, Mexico. Along the horizontal axes, the number of functional groups corresponds to Table G1. 


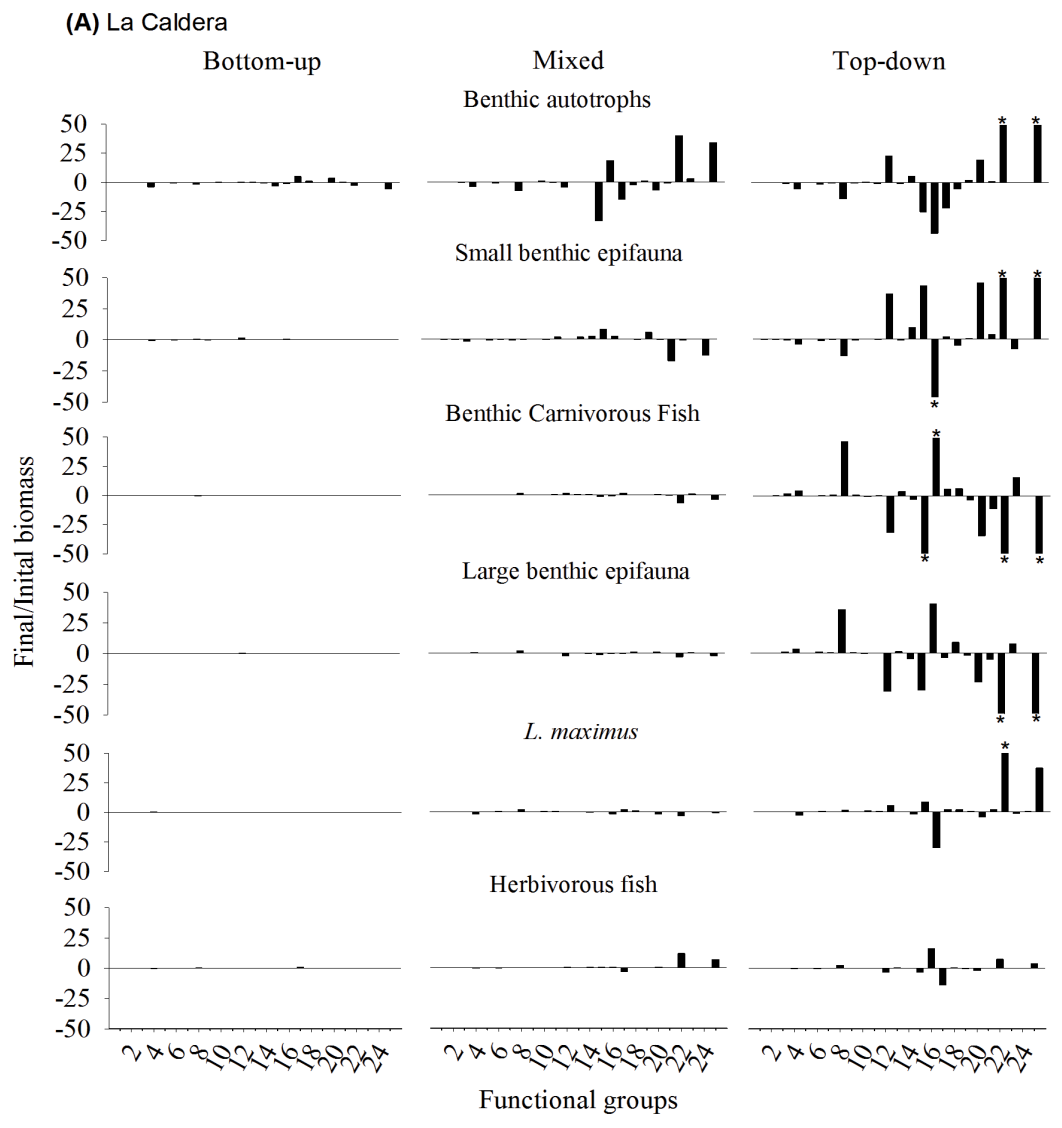

(B) La Baliza

Bottom-up

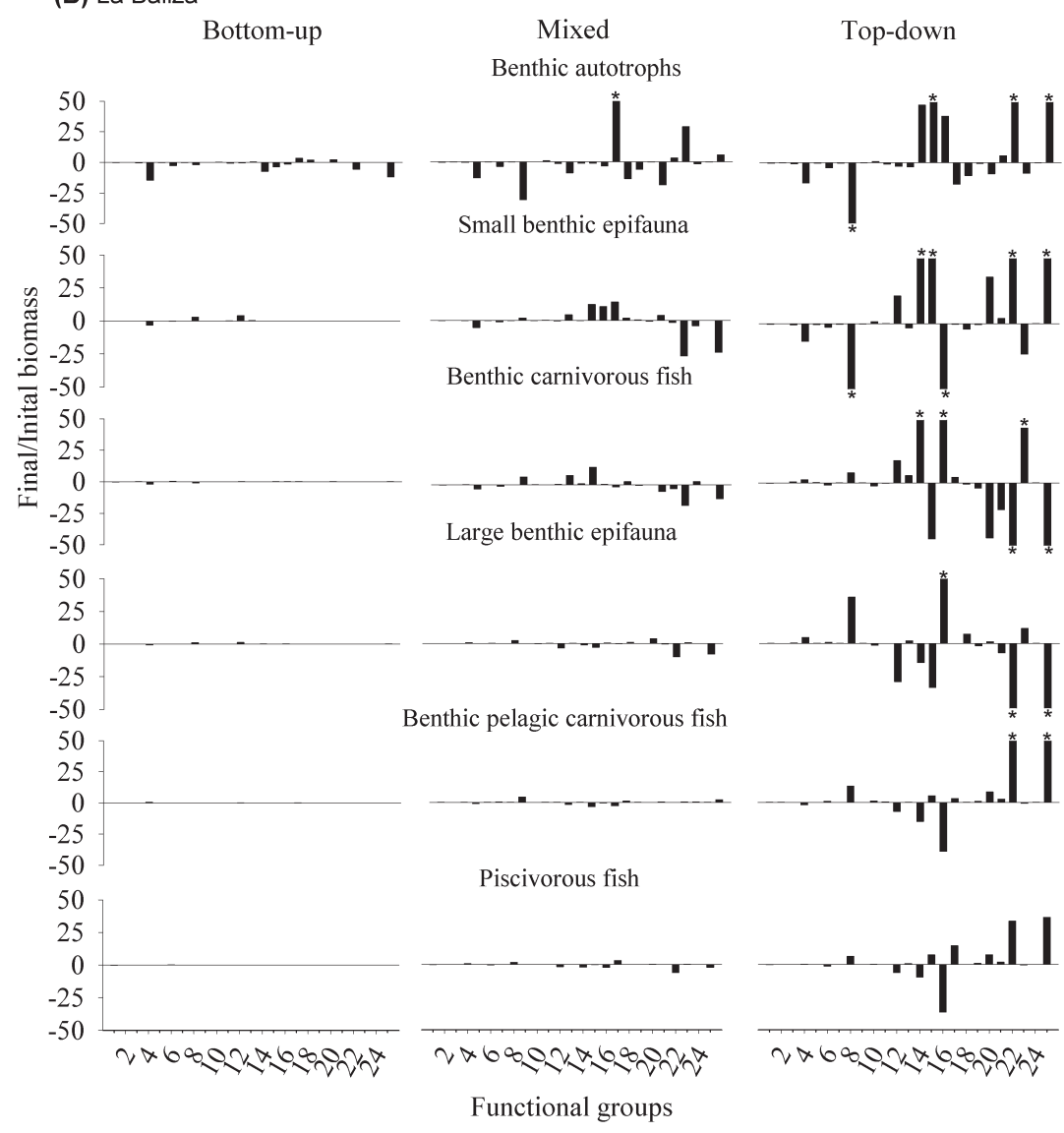

Piscivorous fish 
(C) El Colorado

Bottom-up

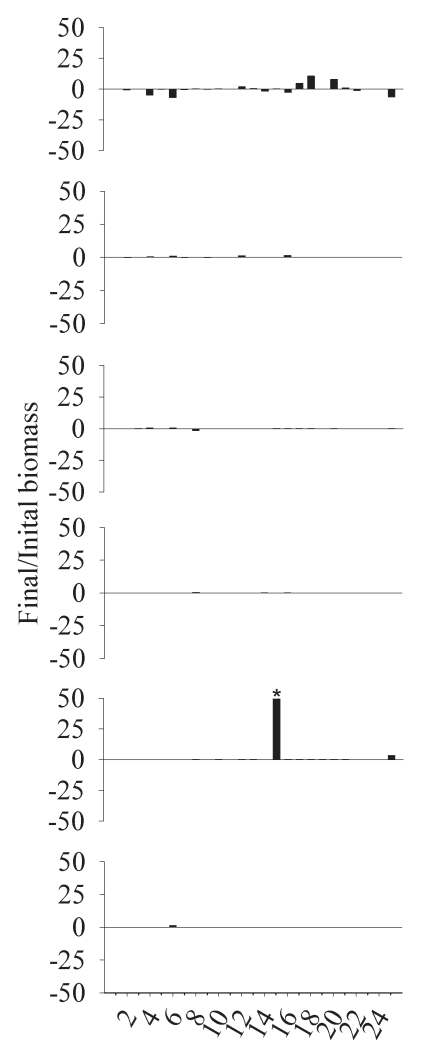

(D) Chancay

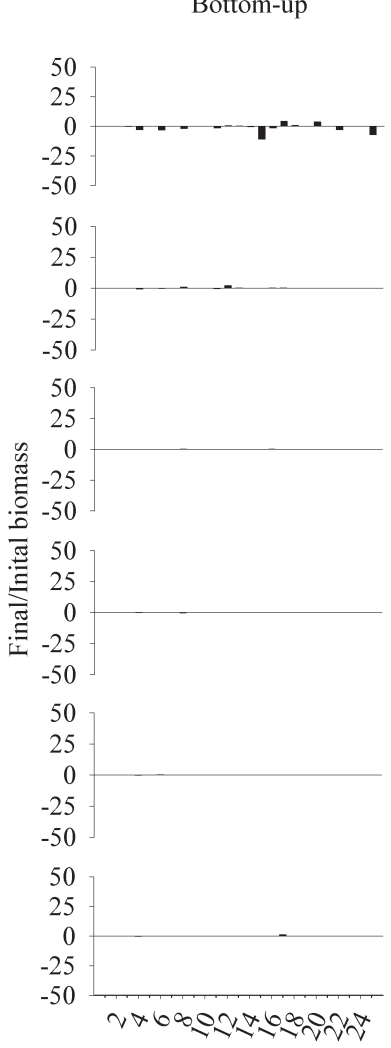

Mixed

Benthic autotrophs

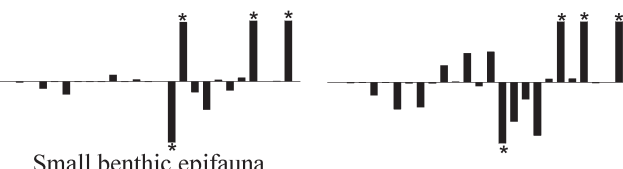

Small benthic epifauna

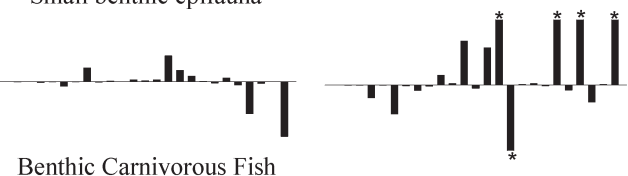

Benthic Carnivorous Fish

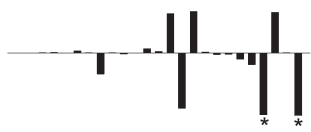

Large benthic epifauna

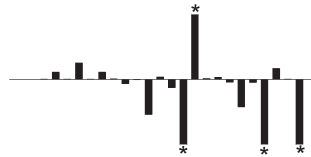

Soft corals

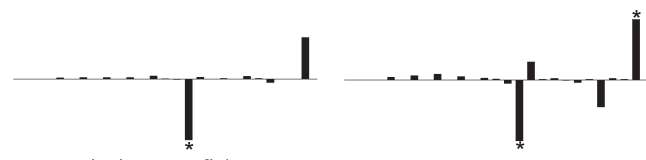

Piscivorous fish

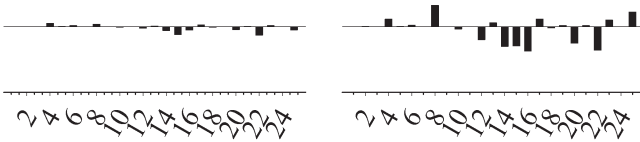

Functional groups

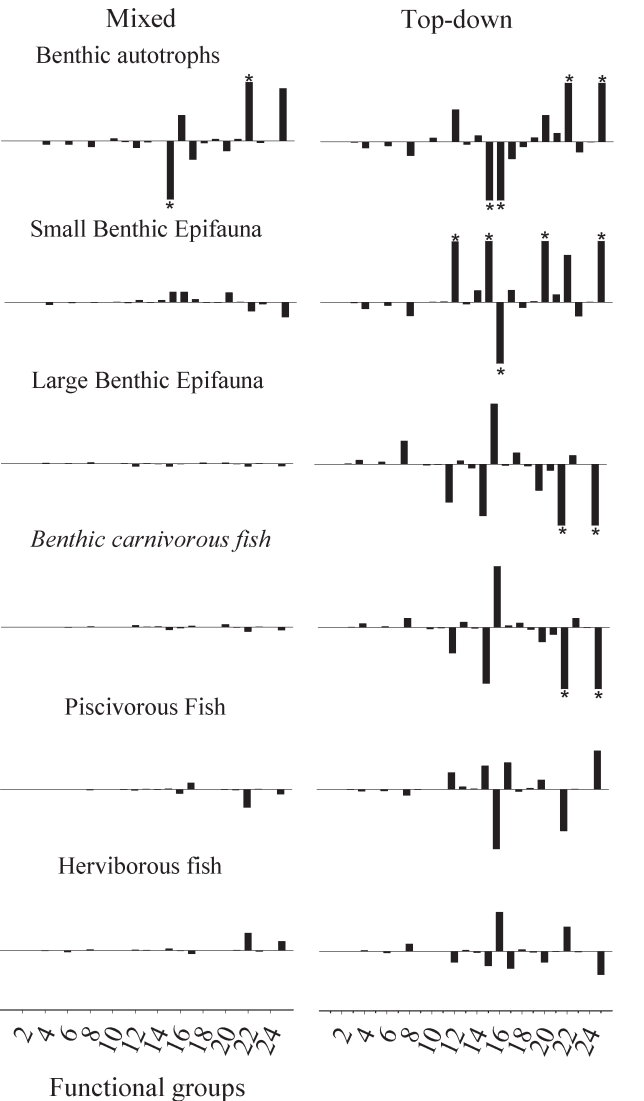



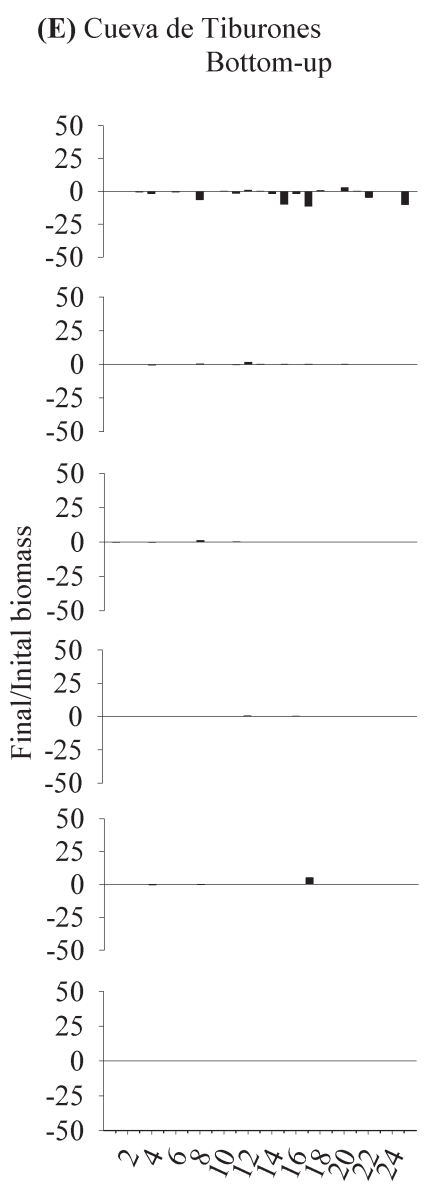

Mixed

Benthic autotrophs

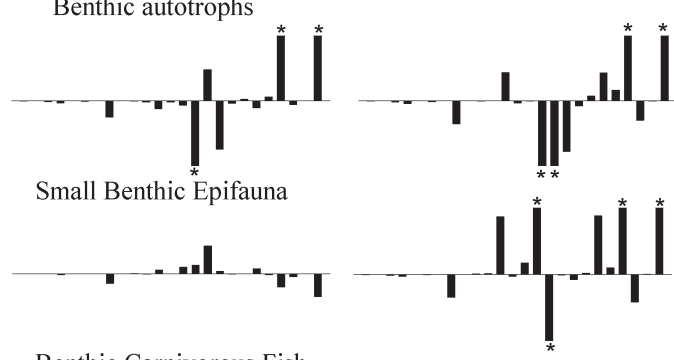

Benthic Carnivorous Fish

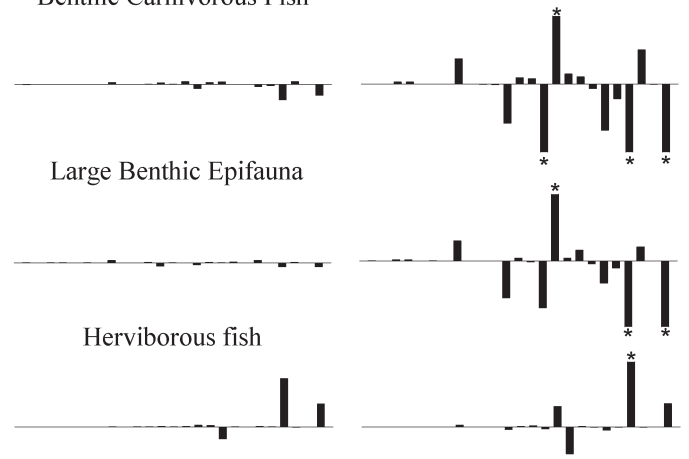

Benthic Pelagic Carnivorous Fish

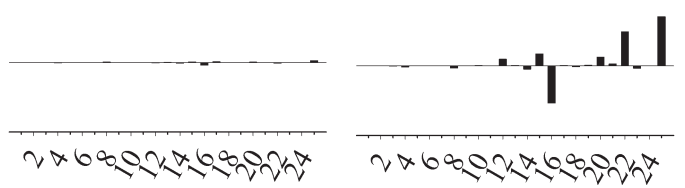

Functional groups

Figure 3. Dynamical responses of the main functional groups' biomass behavior to five fishing areas at Banco Chinchorro Biosphere Reserve, Mexico. (A) La Caldera; (B) La Baliza; (C) El Colorado; (D) Chancay; (E) Cueva de Tiburones. Along the horizontal axes, the number of functional groups correspond to Table G1.

small benthic epifauna (3.5-6.9\%) were the most significant groups in all models.

Total catches and mean trophic level of the catch also differed between models, indicating a highly heterogeneous exploitation. Total catches were highest in El Colorado and lowest at Chancay (Table G2). The highest magnitudes of mean trophic level of the catch were found in El Chancay and La Caldera, exploiting fish feeders such as $M$. bonaci, $S$. barracuda, E. striatus and the piscivorous fish group. Secondary consumers such as $P$. argus and $S$. gigas were mainly exploited in Cueva Tiburones and La Caldera. In the El Colorado model, the level of the catch was intermediate due to higher fishing pressure on $L$. analis, the benthic carnivorous fish group and $P$. argus (Appendix F, Table G1). The highest fishing mortalities $(F)$ were found for: L. analis in El Colorado (0.68); M. bonaci in La Caldera (0.26), El Colorado (0.26) and Chancay $(0.25)$; L. maximus in La Baliza (0.21) and La Caldera (0.18); S. barracuda in La Caldera (0.25); and $P$. argus in La Baliza (0.15). In contrast, the queen conch ( $S$. gigas) presented a low fishing mortality $(0.03)$ in the La Baliza subsystem (Appendix F).

To assess the propagation of the direct and indirect effects estimated using MTI and Ecosim short-term simula- tions, we selected only the six species and functional groups (by subsystem) that propagated higher-order effects through networks. In general terms, quantitative and qualitative differences were found among the five trophic models. The MTI outcomes showed that benthic autotrophs, small benthic epifauna and benthic-pelagic carnivorous fish significantly propagated strong effects on the remaining compartments of the models. Other important groups were the benthic carnivorous fish, large benthic epifauna and herbivorous fish; however, these generated important effects in only three models (Fig. 2). Likewise, soft corals and piscivorous fish propagated important effects in a large number of compartments in $\mathrm{El}$ Colorado and Chancay, while S. barracuda and M. bonaci did so in La Caldera and Cueva de Tiburones, respectively (Fig. 2). The dynamic changes predicted using Ecosim were quite similar to those obtained with MTI. In this case, the benthic autotrophs, small benthic epifauna, benthic carnivorous fish and large benthic epifauna generated the strongest effects through the trophic network in the five model subsystems (Fig. 3a-e). Other groups that caused high impacts were piscivorous fish (in the Chancay, La Baliza and El Colorado models) and herbivorous fish (in the Cueva de Tiburones, La Caldera and Chancay models) (Figs. 3a-3e). Finally, soft coral was important in El Colorado (Fig. 3c) and L. maximus in 
La Caldera (Fig. 3a). Notably, the Ecosim short-term simulations performed using the bottom-up flow control mechanism propagated weak changes in the compartments in all models, while the top-down flow showed the strongest responses.

The $S R T$ estimates showed different patterns among models using bottom-up and mixed-flow controls. The SRT cannot be estimated under a top-down flow control mechanism because the models did not return to the initial (pre-intervention) states. The benthic autotrophs presented the highest $S R T$ values ( 8.5 - 30.8 years) in the La Caldera, La Baliza, El Colorado and Cueva de Tiburones models, while $M$. bonaci (27.8 - 43.8 years) presented the highest $S R T$ values in the Chancay subsystem. Table G3 in Appendix G summarizes the $S R T$ values for all compartments.

\section{Discussion}

The group of benthic autotrophs (dominated by fleshy macroalgae) showed the highest concentration of biomass in the five subsystems studied at Banco Chinchorro. These high biomass values for benthic autotrophs agree with previous reports for other Mexican coral reefs (Arias-González et al. 2004, 2011, Acosta-González et al. 2013). In the Caribbean Sea, the high biomass of fleshy macroalgae has been explained as a consequence of the lower herbivorous pressure exerted by the sea urchin D. antillarum (Hughes 1994), the harvest of large-herbivores (i.e., green turtles, hawksbill turtles, manatees and parrotfish such as Scarus guacamaia) (Jackson et al. 2001, Hughes et al. 2003) and the increase in sediments and nutrients from runoff in the sea water (i.e., phosphate and ammonium concentrations) (Lapointe 1997). However, the purported increase in nutrients should be considered with caution since other studies have not shown evidence of eutrophication in the Caribbean Sea (Hughes et al. 1999). It is currently accepted that a greater dominance of fleshy macroalgae represents a generalized degradation in coral reef ecosystems, reducing the live coral cover (Hughes 1994, Acosta-González et al. 2013). This assumption is corroborated by the results obtained in the present study using MTI because increased macroalgae biomass caused a negative impact on stony coral biomass, as found in other studies (Jackson et al. 2001, Liu et al. 2009, Acosta-González et al. 2013). Likewise, the group of soft corals showed a high level of biomass, forming great mats in Banco Chinchorro (particularly in El Colorado and Chancay). While the relationship of soft coral with other reef organisms is still not well understood, recent studies have shown that soft coral species explain part of the variation in diversity of stony corals and reef fishes in the Mexican Caribbean (Rodríguez-Zaragoza and Arias-González 2015) and in the tropical Mexican Pacific (Rodríguez-Zaragoza et al. 2011). It is widely recognized that soft corals contribute to reef habitat structure and heterogeneity, e.g., the ecosystem-engineer (sensu Jones et al. 1994) or niche-constructor (sensu Levins and Lewontin 1985) species, creating favorable habitat conditions for diverse reef species (Rodriguez-Zaragoza and Arias-González 2015).

With regard to ecosystem growth and development, the Total System Throughput (T) magnitudes for all subsystems were higher than those reported for other coral reef systems, such as the Indo-Pacific (Arias-González et al. 1997, Arias-González and Morand 2006, Liu et al. 2009), Eastern Tropical Pacific (Okey et al. 2004) and the Caribbean Sea (Opitz 1996, Arias-González et al. 2004, Rodríguez-Zaragoza 2007). However, our results were similar to those described for the Mahahual and Yuyum reefs located off the Mexican Caribbean coast (facing Banco Chinchorro) (RodríguezZaragoza 2007). The high magnitudes of $T$ could be mainly explained by the high biomass of the benthic autotrophs and by the flow towards the detritus, coinciding with the report of Ortiz (2008). The Ascendency, Overhead, Development Capacity, $A / C, O v / C$ ratios and Internal Redundancy all indicated that Cueva de Tiburones would be the most developed, organized and healthy ecological subsystem, but also the subsystem less resistant to perturbations, which could be explained by the lower harvest pressure exerted on this subsystem. By means of ecological modeling, it has been shown that fishing affects the development and growth of ecosystems, since high harvest pressure can decrease the organization of energy flows that increase resistance of the system to perturbations (e.g., Ortiz et al. 2013, 2015, Cáceres et al, 2016). It is important to indicate, however, that all model systems in Banco Chinchorro would present higher degrees of development and lower ecosystem resistance to disturbances compared with other coral reefs in the Caribbean Sea and the central Pacific (e.g., Arias-González et al. 2004, 2011, Arias-González and Morand 2006). These outcomes reveal the need to focus more effort into protection of the Banco Chinchorro from human activities (e.g., fisheries and tourism activities). Fortunately, Chancay is located in the core zone of the Biosphere Reserve, facilitating its surveillance.

In relation to the food web structure, however, the total number of trophic pathways and mean length of pathways calculated for all subsystems of Banco Chinchorro were higher than those described for some Mexican Caribbean coastal reefs (Rodríguez-Zaragoza 2007). Moreover, all subsystems showed more complex trophic networks (in terms of pathway number) than those reported for reefs in the Indo-Pacific (Arias-González and Morand 2006). Nevertheless, the system omnivory index for the five subsystems revealed similar magnitudes compared to models constructed for other coral reefs ecosystems (Arias-González and Morand 2006), coastal lagoons (Vega-Cendejas et al. 2001) and benthic communities of temperate systems (Ortiz 2008, Taylor et al. 2008, Ortiz et al. 2010).

The analyses of fishing impacts on networks showed that the mean trophic level of catch in this study was similar to those described for other coral reefs (Arias-González et al. 2004, Rodríguez-Zaragoza 2007, Liu et al. 2009) and mainly indicated exploitation of organisms from high and intermediate trophic levels. The results of this study suggest that the effects of the fisheries of Banco Chinchorro have not yet generated such a severe disturbance in the ecosystem, such as would be the case with a process of fishing down the food web - which occurs when there is a considerable reduction in the population size of the large predatory fishes at the top of the food webs-, as has been observed in other 
marine ecosystems (Pauly et al. 1998). The fishing mortality $(F)$ estimates for M. bonaci, S. barracuda, L. analis and $L$. maximus demonstrate that these species are highly exploited; therefore, efforts must be directed towards the implementation of fisheries management strategies for these fish species. In contrast, the $F$ estimated for $P$. argus and $S$. gigas (the most important target species at Banco Chinchorro) showed low overall values compared to other studies (de Jesús-Navarrete et al. 2003, Sosa-Cordero 2003,). While this suggests that the harvest of both species would be currently sustainable, our results should be treated with caution because the model did not include illegal fishing of these species.

The propagation of direct and indirect effects estimated by MTI and Ecosim short-term dynamic simulations was quite similar, indicating that benthic autotrophs (mainly fleshy macroalgae) produce the highest impacts on the remaining compartments. In the Caribbean Sea, it is known that macroalgae reduce live coral cover - provoking phase shifts -, which is what alters the food web structure and ecosystem properties of coral reefs (Hughes 1994, Jackson et al. 2001) and decreases overall biodiversity (Acosta-González et al. 2013). Other compartments with relevant impacts on the remaining variables were the fish species $M$. bonaci, $S$. barracuda and $L$. maximus and the functional groups benthicpelagic carnivorous fish, benthic carnivorous fish, herbivorous fish and piscivorous fish. Most of these organisms exert a strong top-down control (through predation) of the species at different trophic levels (autotrophs, secondary and tertiary consumers). Since these compartments could propagate important impacts throughout the network, their exploitation requires careful monitoring. Additionally, both small and large benthic epifauna also had strong direct and indirect effects on the remaining compartments. However, these results must be treated with caution since these functional groups included a large number of invertebrate organisms without accurate ecological information.

At present, the fishing bans in Banco Chinchorro apply only to $S$. gigas and $P$. argus, without controlling the exploitation of fish and other reef species. We consider that it is important to design and execute a global management strategy to prioritize regulation of the harvest of $M$. bonaci, which in the model caused important impacts through the networks and is the most important top-predator in the coral reefs. The harvest of $S$. barracuda, E. striatus, Lutjanus analis and Lachnolaimus maximus, carnivorous fish such as Anisotremus virginicus, Calamus pennatula, Epinephelus guttatus and Haemulon album should be carefully monitored and eventually controlled since all of these species are located at intermediate trophic levels and affect the ecosystem structure. Although catches of herbivorous fish have not been officially reported in Banco Chinchorro, some authors of this paper (Castro-Pérez J.M. and Rodríguez-Zaragoza F.A. pers. obs.) have detected occasional extractions of species such as Scarus vetula, Sparisoma viride and S. guacamaia for selfconsumption (subsistence fishing). It is important to raise awareness among the fishing cooperatives about the risks of exploiting these fishes, given their essential role in controlling benthic autotrophs, especially since other herbivores such as $D$. antillarum would not be effective controllers of macroalgae in this coral reef. Most of the compartments that increased the $S R T$ (reducing resilience capacity) coincided with the results obtained from the MTI and Ecosim simulations. The benthic autotrophs showed the highest magnitudes of SRT of all the subsystems studied, highlighting the importance of this group within the ecosystem.

The information contained herein allows evaluation of the status of ecosystem health in the Banco Chinchorro Biosphere Reserve, and would also be useful for the design of sustainable multispecies management strategies for fisheries (Pauly et al. 2002), particularly considering that protected marine areas could restore the populations and ecological networks of adjacent highly exploited systems (Arias-González et al. 2004). Additional management plans should be implemented to complement the five-year ban (beginning in July 2011) on exploitation of $S$. gigas. We recommend expanding the bans primarily to include the following six fish species: M. bonaci, S. barracuda, E. striatus, L. analis, L. maximus, and $L$. griseus. The harvest of other commercial and noncommercial benthic carnivorous, piscivorous, and benthicpelagic carnivorous fish should be strictly monitored.

Given the known limitations and shortcomings of the Ecopath and Ecosim theoretical frameworks (Christensen and Walters 2004), and recognizing that ecological processes occur in changing environments (Levins 1968), the models constructed and the simulation executed in the present study represent the processes underlying these systems only when considering their short-term dynamics (Ortiz 2008, Ortiz et al. 2010, 2013, 2015). While this strategy differs from Melbouerne-Thomas et al. (2011), who modeled changes in the community composition of five sub-regions of the Mesoamerican Barrier Reef System for 25.5 and 100 years, both approaches concluded that increased macroalgae coverage has a negative impact on live coral cover. Finally, the present study shows the need to assess the trajectory followed by the different subsystem compartments, the macrodescriptors and resistance and resilience. We also suggest implementation of quantitative spatial simulations and semiquantitative loop models that include other types of ecological relationships, as well as the identification of keystone species complexes defined as a core of species with keystoneness properties (sensu Ortiz et al. 2013). All of this would allow implementation of an adaptive fishing management regime (sensu Francis et al. 2007), improving management strategies and maximizing conservation of the natural resources in the Banco Chinchorro Biosphere Reserve.

Acknowledgements. This study was financed by the World Wildlife Fund (WWF)-México, the Comisión Nacional de Areas Naturales Protegidas (CONANP), and Universidad de Guadalajara. We are grateful to G. Acosta and R. Hernández at CINVESTAV-IPN for their help in the laboratory work; as well as to G. Muñoz, A. Vega, and J.J. Domínguez at CONANP, and the fishing cooperatives of "Langosteros del Caribe" and "Pescadores de Banco Chinchorro" for their help in the fieldwork. We also thank to Pi-Jen Liu (National Chung Hsing University, Taiwan), who estimated the coral and mac- 
roalgae biomass. This work is part of the first author's postdoctoral research grant at Instituto Antofagasta de Recursos Naturales Renovables, Universidad de Antofagasta, Chile.

\section{References}

Acosta-González, G., F.A. Rodríguez-Zaragoza, R.C. HernándezLanda and J.E. Arias-González. 2013. Additive diversity partitioning of fish in a Caribbean coral reef undergoing shift transition. PLoS ONE 8(6): e65665. doi:10.1371/journal. pone. 0065665 .

Ainsworth, C.H., D.A. Varkey and T.J. Pitcher. 2008. Ecosystem simulations supporting ecosystem-based fisheries management in the Coral Triangle, Indonesia. Ecol. Model. 214: 361-374.

Arias-González, J.E. and S. Morand. 2006. Trophic functioning with parasites: a new insight for ecosystem analysis. Mar. Ecol. Prog. Ser. 320: 43-53.

Arias-González, J.E., B. Delesalle, B. Salvat and R. Galzin. 1997. Trophic functioning of the Tiahura sector "Moorea Island, French Polynesia”. Coral Reefs 16: 231-246.

Arias-González, J.E., E. Nuñez-Lara, C. González-Salas and R. Galzin. 2004 Trophic models for investigation of fishing effect on coral reef ecosystems. Ecol. Model. 172: 197-212.

Arias-González, J.E., C. González-Gándara , J.L. Cabrera and V. Christensen. 2011. Predicted impact of the invasive lionfish Pterois volitans on the food web of a Caribbean coral reef. Environ. Res. 111: 917-925.

Begon, M., J.L. Harper and C.R. Townsend. 1990. Ecology: Individuals, Populations and Communities. 2nd ed. Blackwell Scientific Publications, Oxford.

Beltrán-Torres, A.U. and J.P. Carricart-Ganivet. 1999. Lista revisada y clave para los corales pétreos zooxantelados (Hydrozoa: Milleporina; Anthozoa: Scleractinia) del Atlántico mexicano. Rev. Biol. Trop. 47: 813-829.

Beltrán-Torres, A.U., Muñoz-Sánchez L. and Carricart-Ganivet J.P. 2003. Effects of hurricane Keith at a patch reef on Banco Chinchorro, Mexican Caribbean. Bull. Mar. Sci. 73(1): 187-196.

Bondavalli, C., A. Bodini, G. Rossetti and S. Allesina. 2006. Detecting stress at the whole-ecosystem level: the case of a mountain lake (Lake Santo, Italy). Ecosystems 9: 768-787.

Cáceres I., Ortiz M., Cupul-Magala A.L. and Rodríguez-Zaragoza F.A. 2016. Trophic models and short-term simulations for the coral reefs of Cayos Cochinos and Media Luna (Honduras): a comparative network analysis, ecosystem development, resilience and fishery. Hydrobiologia 770: 209-224.

Chávez, E.A. and E. Hidalgo. 1987. Los arrecifes coralinos del Caribe noroccidental y Golfo de México en el contexto socioecónomico. An. Inst. Cienc. Mar Limnol. UNAM 15: 167-176.

Christensen, V. 1995. Ecosystem maturity-toward quantification. Ecol. Model. 77: 3-32.

Christensen, V. and D. Pauly. 1992. Ecopath II: a software for balancing steady-state ecosystem models and calculating network characteristics. Ecol. Model. 61: 169-185.

Christensen, V. and D. Pauly. 1993. Flow characteristics of aquatic ecosystem. In: Christensen, V. and D. Pauly (eds), Trophic Models of Aquatic Ecosystems. ICLARM Conf. Proc. 26: 338352.

Christensen, V. and C. Walters. 2004. Ecopath with Ecosim: methods, capabilities and limitations. Ecol. Model. 172: 109-139.

Costanza, R., M. Mageau and B. Norton. 1998. Patten B Predictors of Ecosystem Health. In: Rapport, D., R. Costanza, P. Epstein,
C. Gaudet and R. Levins (eds), Ecosystem Health. Blackwell Science: MA, pp. 240-250.

Cruz-Piñón, G., J.P. Carricart-Ganivet and J. Espinosa-Avalos. 2003. Monthly skeletal extension rates of the hermatypic corals Montastraea annularis and Montastraea faveolata: biological and environmental controls. Mar. Biol. 143: 491-500.

de Jesús-Navarrete, A., A. Medina-Quej and J.J. Oliva-Rivera. 2003. Changes in the queen conch (Strombus gigas L.) population structure at Banco Chinchorro, Quintana Roo, México, 19901997. Bull. Mar. Sci. 73: 219-229.

Francis, R., M. Hixon, M. Clarke, S. Murawski and S. Ralston. 2007. Ten commandments for ecosystem-based fisheries scientists. Fisheries 32: 217-233.

González, A., D. Torruco-Gomez, A. Liceaga-Correa and J. Ordaz. 2003. The shallow and deep bathymetry of the Banco Chinchorro reef in the Mexican Caribbean. Bull. Mar. Sci. 73: 15-22.

Guénette, S., V. Christensen and D. Pauly. 2008. Trophic modelling of the Peruvian upwelling ecosystem: towards reconciliation of multiples datasets. Prog. Oceanogr. 79: 326-335.

Holling, C.S. 1973. Resilience and stability of ecological systems. Annu. Rev. Ecol. Syst. 4: 1-23.

Hughes, T.P. 1994. Catastrophes, phase shifts, and large-scale degradation of a Caribbean coral reef. Science 265: 1547-1551.

Hughes, T.P., A.M. Szmant, R. Steneck, R. Carpenter and S. Miller. 1999. Algal blooms on coral reefs: What are the causes? Limnol. Oceanogr. 44(6): 1583-1586.

Hughes, T.P., A.H. Baird, D.R. Bellwood, M. Card, S.R. Connolly, C. Folke, R. Grosberg, O. Hoegh-Gulberg, J.B.C. Jackson, J. Kleypas, J.M. Lough, P. Marshall, N. Myström, S.R. Palumbi, J.M. Pandolfi, B. Rosen and J. Roughgarden. 2003. Climate change, human impacts, and the resilience of coral reefs. Science 301: 929-933.

Humann, P. and DeLoach N. 2013a. Reef Coral Identification: Florida, Caribbean, Bahamas. 3rd Edition New World Publications Press. Florida, USA.

Humann, P. and DeLoach N. 2013b. Reef Creature Identification: Florida Caribbean Bahamas. 3rd Edition New World Publications Press. Florida, USA.

INE. 2000. Programa de Manejo Reserva Banco Chinchorro. Instituto Nacional de Ecología, México

Jackson, J.B.C., M.X. Kirby, W.H. Berger, K.A. Bjordal, L.W. Botsford, B.J. Bourque, R.H. Bradbury, R. Cooke, J. Erlandson, J.A. Estes, T.P. Hughes, S. Kidwell, C.B. Lange, H.S. Lenihan, J.M. Pandolfi, C.H. Peterson, R.S. Steneck, M.J. Tegner and R.R. Warner. 2001. Historical overfishing and the recent collapse of coastal ecosystems. Science 293: 629-638.

Jones, C., J. Lawton and M. Shachak. 1994. Organism as ecosystem engineers. Oikos 69: 373-386.

Jordán, E. and E. Martín. 1987. Banco Chinchorro: morphology and composition of a caribbean atoll. Atoll. Res. Bull. 310: 1-25.

Jordán, F., M. Scotti, Á. Mike and M. Ortiz. 2014. Strong asymmetrical inter-specific relationships in food web simulations. Mar. Ecol. Prog. Ser. 512: 89-98.

Lapointe, B.E. 1997. Nutrient thresholds for bottom-up control of macroalgal blooms on coral reefs in Jamaica and southest Florida. Limnol. Oceanogr. 42: 1119-1131.

Levins, R. 1968. Evolution in Changing Enviroments. Princeton University, Princeton NJ.

Levins, R. and R. Lewontin. 1985. The Dialectical Biologist. Harvard University, MA. 
Liu, P.J., S. Kwang-Tsao, J. Rong-Quen, F. Tung-Yung, W. SaouLien, H. Jiang-Shiou, C. Jen-Ping, C. Chung-Chi and L. HsingJuh. 2009. A trophic model of fringing coral reefs in Nanwan Bay, southern Taiwan suggests overfishing. Mar. Environ. Res. 68: 106-117.

Melbourne-Thomas, J., C.R. Johnson and E.A. Fulton. 2011 Regional-scale scenario analysis for the Meso-American Reef system: modelling coral reef futures under multiple stressors. Ecol. Model. 222: 1756-1770.

Merino-Ibarra, M. 1986. Aspectos de la circulación costera superficial del Caribe mexicano con base en observaciones utilizando tarjetas de deriva. An. Inst. Cienc. Mar Limnol. UNAM 13: 31-46.

Monaco, M., R. Ulanowicz. 1997. Comparative ecosystem trophic structure of three U.S. mid-Atlantic estuarios. Mar. Ecol. Prog. Ser. 161: 239-254.

Okey, T.A., S. Banks, A.F. Born, R.H. Bustamante, M. Calvopiña, J.E. Graham, E. Espinoza, J.M. Fariña, L.E. Garske, G.K. Recke, S. Salazar, S. Shepherd, V. Toral-Granda and P. Wallem. 2004. A trophic model of a Galápagos subtidal rocky reef for evaluating fisheries and conservation strategies. Ecol. Model. 172: 383-401.

Opitz, S. 1996. Trophic Interactions in Caribbean Coral Reefs. ICLARM, Manila, Philippines.

Ortiz, M. 2008. Mass balanced and dynamics simulations of trophic models of kelp ecosystems near the Mejillones Peninsula of northern Chile (SE Pacific): comparative network structure and assessment of harvest strategies. Ecol. Model. 216: 31-46.

Ortiz, M., M. Avendaño, M. Cantillañez, F. Berrios and L. Campos. 2010. Trophic mass balanced models and dynamic simulations of benthic communities from La Rinconada Marine Reserve off northern Chile: network properties and multispecies harvest scenario assessments. Aquat. Conserv. Mar. Freshw. Ecosyst. 20: $58-73$

Ortiz, M., R. Levins, L. Campos, F. Berrios, F. Campos, F. Jordán, J. González and F.A. Rodríguez-Zaragoza. 2013 Identifying keystone trophic groups in benthic ecosystems: implications for fisheries Management. Ecol. Indic. 25: 133-140.

Ortiz, M., L. Campos, F. Berrios, F.A. Rodríguez-Zaragoza, B Hermosillo and J. González. 2015. Mass balanced trophic models and short-term dynamical simulations for benthic ecological systems of Mejillones and Antofagasta bays (SE Pacific): comparative network structure and assessment of human impacts. Ecol. Model. 309-310: 153-152.

Pauly, D., V. Christensen, J. Dalsgaard, R. Froese and F. Torres. 1998 Fishing down marine food webs. Science 279: 860-863.

Pauly, D., V. Christensen, S. Guénette, T.J. Pitcher, U.R. Sumaila C.J. Walters, R. Watson and D. Zeller. 2002. Towards sustainability in world fisheries. Nature 418: 689-695.

Pimm, S.L. 1982. Food Webs. Chapman and Hall, NY, USA.

Polovina, J.J. 1984. Model of a coral reef ecosystem: I the Ecopath model and its application to French Frigate Shoals. Coral Reefs 3: $1-11$.

Robertson, D.R., Peña E.A., Posada J.M. and Claro R. 2015 Shorefishes of the Greater Caribbean: online information system. Version 1.0 Smithsonian Tropical Research Institute, Balboa, Panamá

Rodríguez-Zaragoza, F.A. 2007. Biodiversidad y funcionamiento de los ecosistemas arrecifales costeros del Caribe mexicano. Ph.D. thesis, Centro de Investigación y Estudios Avanzados, UnidadMérida, México, 344 pp.

Rodríguez-Zaragoza, F.A., A.L. Cupul-Magaña, C.M. Galván-Villa, E. Ríos-Jara, E.g., Robles-Jarero, E. López-Uriarte and J.E. Arias-González. 2011. Additive partitioning of reef fish diver- sity variation: a promising marine biodiversity management tool. Biodivers. Conserv. 20: 1655-1675.

Rodríguez-Zaragoza, F.A. and J.E. Arias-González. 2015. Coral biodiversity and bio-construction in the northern sector of the Mesoamerican reef system. Front. Mar. Sci. 2: 13. doi: 10.3389/ fmars.2015.00013.

Ricker, W. E. 1968. Food from the sea. In: Committee on Resources and Man (eds), Resource and Man. US National Academy of Sciences, Chap 5. W. H. Freeman, San Francisco, pp. 87-108.

Scotti, M., N. Gjata, C. Livi and F. Jordán. 2012. Dynamical effects of weak trophic interactions in a stochastic food web simulation. Community Ecol. 13: 230-237.

Sosa-Cordero, E. 2003. Trends and dynamics of the spiny lobster, Panulirus argus, resource in Banco Chinchorro, Mexico. Bull. Mar. Sci. 73: 203-217.

Taylor, M.H., M. Wolff, J. Mendo and C. Yamashiro. 2008. Changes in trophic flow structure of Independence Bay (Peru) over an ENSO cycle. Prog. Oceanogr. 79: 336-351.

Ulanowicz, R. 1986. Growth and Development: Ecosystems Phenomenology. Springer, NY.

Ulanowicz, R. 1997. Ecology, the Ascendant Perspective. Complexity in Ecological Systems Series. NY. Columbia University Press.

Ulanowicz, R. and Ch. Puccia.1990. Mixed trophic impacts in ecosystems. Ceonoses 5: 7-16.

Vega-Cendejas, M.E. and F. Arreguín-Sánchez. 2001. Energy fluxes in a mangrove ecosystem from a coastal lagoon in Yucatan Peninsula, Mexico. Ecol. Model. 137: 119-133.

Vega-Zepeda, A., H. Hernández-Arana and J.P. Carricart-Ganivet. 2007. Spatial and size-frequency distribution of Acropora (Cnidaria: Scleractinia) species in Chinchorro Bank, Mexican Caribbean: implications for management. Coral Reefs 26: 671676.

Villegas-Hernández, H., C. González-Salas, A. Aguilar-Perera and A.J. López-Gómez. 2008. Settlement dynamics of the coral reef fish Stegastes partitus, inferred from otolith shape and microstructure analysis. Aquat. Biol. 1: 249-258.

Walters, C.J., V. Christensen and D. Pauly. 1997. Structuring dynamic models of exploited ecosystems from trophic mass-balance assessments. Rev. Fish. Biol. Fish. 7: 139-172.

Walter, C.J., D. Pauly, V. Christensen and J. Kitchell. 1999. Representing density dependent consequences of the life history strategies in aquatic ecosystems: ECOSIM II. Ecosystems 3: $70-83$.

Weijerman, M., E.A. Fulton and F.A. Parrish. 2013. Comparison of coral reef ecosystems along a fishing pressure gradient. PLoS ONE 8(5):e63797. doi: 10.1371/journal.pone.0063797.

Received September 15, 2015
Revised February 14, 2016

Accepted March 2, 2016

\section{Electronic appendices}

\section{Appendix A}

Habitat characteristics of subsystems.

\section{Appendix B}

Fish assemblages and reef habitat structure and Multivariate community analysis.

\section{Appendix C}

Ecopath and Ecosim equations and Ascendency theoretical framework. 


\section{Appendix D}

Table D1. Fish functional groups used in Ecopath with Ecosim (Ewe) models.

Table D2. Other non fish functional groups used in Ecopath with Ecosim (Ewe) models.

Table D3. Diet composition (\%) used in the Ecopath model at La Caldera, Chinchorro Bank Biosphere Reserve, México.

Table D4. Diet composition (\%) used in the Ecopath model at La Baliza, Chinchorro Bank Biosphere Reserve, México.

Table D5. Diet composition (\%) used in the Ecopath model at El Colorado, Chinchorro Bank Biosphere Reserve, México.

Table D6. Diet composition (\%) used in the Ecopath model at Chancay, Chinchorro Bank Biosphere Reserve, México.

Table D7. Diet composition (\%) used in the Ecopath model at Cueva de Tiburones, Chinchorro Bank Biosphere Reserve, México.

Table D8. Data sources used to build the Ecopath models. Small numbers located at functional groups's right position correspond to ecological subsystems.

\section{Appendix E}

Fig. E1. Flow diagrams of each Ecopath model.

\section{Appendix F}

Table F1. Fishing and natural mortality rates of target species and functional groups in each Ecopath model.

\section{Appendix G}

Table G1. Parameter values entered (standard) and estimated (in bold) by Ecopath with Ecosim for each ecological system studied at Banco Chinchorro Biosphere Reserve, México.

Table G2. Summary statistics after mass-balance process by Ecopath with Ecosim (A) and network flow indices (B) for each ecological system studied at Banco Chinchorro Biosphere Reserve, México.

Table G3. Summary of the system recovery time $(S R T)$ for each ecological system studied at Banco Chinchorro Biosphere Reserve, Mexico, using three flow control mechanisms.

The files may be downloaded from www.akademiai.com. 